\title{
Revisiting Managerial Ownership and Firm Value in the Absence of Market Forces: Evidence from Singapore and Thailand*
}

\author{
Sirapat POLWITOON ${ }^{1}$, Oranee TAWATNUNTACHAI ${ }^{2}$
}

Received: May 31, 2020 Revised: June 14, 2020 Accepted: July 03, 2020

\begin{abstract}
This study examines the effect of managerial ownership on firm value in capital markets where outside governance mechanisms to discipline managers are weak or non-existent. We hypothesize that strong market forces in the U.S. confound the effect of managerial ownership on firm value, i.e., the convergence of interest argument. We test the hypothesis using data from 112 firms from Singapore Stock Exchange and 205 firms from the Stock Exchange of Thailand prior to the Asian financial crisis in 1997 when the market forces were weak, yet the investor protection was sufficient to prevent outright appropriation from management. For ease of comparison, we use methodologies from studies done on the U.S. sample firms during the same study period as ours. We find that, both in Singapore and Thailand, firm value is a function of managerial ownership, and the relation is of the famous inverted U-shaped. Moreover, the relation is robust under different model specifications. The results from Thai sample, with weaker market forces than in Singapore, lend support to many agency cost hypotheses advanced in the U.S. Our results provide useful implication for investors in emerging and frontier markets where outside governance mechanisms are yet to be fully developed.
\end{abstract}

Keywords: Agency Cost, Corporate Governance, Endogeneity, Southeast Asia

JEL Classification Code: G30, G32, G34

\section{Introduction}

This paper reexamines the relationship between managerial ownership and firm value in capital markets where outside governance mechanisms such as market for corporate control, industry concentration, and shareholder activism are virtually non-existent. The traditional point of

\footnotetext{
*Acknowledgements:

We gratefully acknowledge advice and suggestions provided by Henry Oppenheimer. For comments on an earlier version, we would like to thank S. Ghon Rhee, Piman Limphapayom, Kenneth Kim and conference participants at PACAP in Melbourne, EFA in Baltimore, and FMA in Toronto. Financial support from the Sigmund Weis School of Business is greatly appreciated.

${ }^{1}$ First Author and Corresponding Author. Associate Professor of Finance, Sigmund Weis School of Business, Susquehanna University, USA [Postal Address: 514 University Avenue, Selinsgrove, PA 17870, USA] Email: polwitoon@susqu.edu

${ }^{2}$ Associate Professor of Finance, School of Business Administration, Penn State Harrisburg, USA. Email: oxt4@psu.edu

(c) Copyright: The Author(s)

This is an Open Access article distributed under the terms of the Creative Commons Attribution Non-Commercial License (http://Creativecommons.org/licenses/by-nc/4.0/) which permits unrestricted noncommercial use, distribution, and reproduction in any medium, provided the original work is properly cited.
}

view, from Jensen and Meckling (1976), suggests that stock ownership is an important mechanism to align the interests of managers with those of shareholders. Large bodies of theoretical works, (Stulz, 1988; Harris \& Raviv, 1988), and empirical research, (Morck, Shleifer \& Vishny, 1988; McConnell \& Servaes, 1990; Fahlenbrach \& Stulz, 2009), find that firm value is positively correlated with managerial ownership and the relation is of an inverted U-shape.

The empirical findings on the relation of managerial ownership and firm value are somewhat marred by the problems of endogeneity and causation (Demsetz \& Lehn, 1985; Villalonga, 2019). Others such as Lederer and Martin (1997) and Cho (1998) empirically show that management ownership is a function of firm value. This implies that managers own more shares because their firms have better prospects, and not vice versa. More recently, Fabisik, Fahlenbrach, Stulz and Taillard (2019) use a large sample of all cap U.S. firms from 1988 to 2015 to show that firm value is negatively related to managerial ownership. Their results on large firms are, however, consistent with the findings from prior literature that the relation is increasing and concave i.e. the humped shape or the inverted U-shape. 
Jensen (1993) suggests that managerial behavior is influenced by both inside and outside governance mechanisms. For example, Kim and Lu (2011) show that the relation between managerial ownership and firm value depends on the strength of external governance. Aggarwal, Erel, Ferreira and Matos (2011) find that international institution investment improves firm value (see also $\mathrm{Vu}$, Phan and Dang, 2020 on Vietnamese sample). Faccio and Lasfer (1999) find no relations on the U.K. sample and attribute their findings to the fact that U.K. provide stronger outside governance mechanisms than the U.S.

In the U.S. and U.K., the market for corporate control and investor protection are very well developed and active; consequently, there is a view that managerial behavior in the U.S. is much influenced by the outside governance mechanisms (Shleifer \& Vishny, 1997; Faccio \& Lasfer, 1999). If this view is accurate, one reason that empirical works on the U.S. market do not find overwhelming evidence to support the argument that managerial ownership affects firm performance is that the effect of managerial ownership is confounded by the effect of the outside governance mechanisms.

This paper attempts to examine the relation between managerial ownership and firm value in the absence of strong market forces. We hypothesize that: 1) if the relationship between ownership and firm value exists, we would be more likely to find the relation in such market environment, and 2) since the causality could go in either direction, the consistency of the relation between ownership and firm value obtained from different model specifications used by previous studies should provide us with some confidence regarding whether firm value is a function of ownership.

For ease of comparison, we choose model specifications from studies done in the U.S. at the same time period as our study. The weak empirical support from U.S. studies has put the convergence of interest hypothesis on a questionable ground. By replicating different model specifications used in previous studies, we believe that the results from the alternative setting free of strong market forces can help provide further empirical evidence on the issue of the relation between ownership and firm value. We test the hypotheses on Singapore and Thailand before the Asian financial crisis. After the crisis, many Asian capital markets have engaged in corporate governance reform to improve the outside governance mechanisms such as disclosure, shareholder rights, and contract laws.

Thailand is suitable as an alternative setting to study this relationship. First, unlike that in the U.S., there is no active market for corporate control to discipline managers and boards of directors in Thailand (Johnson, Boone, Breach \& Friedman, 2000). This condition implies that inside mechanisms such as ownership and monitoring from block holders are likely to affect managerial decision (La Porta, Lopez-de-Silanes, Shleifer \& Vishny, 1998; 2000).

Second, unlike such countries as Russia, Indonesia and Italy, Thailand and Singapore provide some level of investor protection (La Porta et al., 2000). This legal environment helps prevent managers from outright appropriation, thus making managers become relatively more accountable to shareholders than in countries where investor protection is weaker. Third, unlike Japan and Korea, the corporate governance mechanisms such as the keiretsu in Japan and cheobol in Korea do not exist in Thailand. The extent studies on these types of corporate governance suggest that firms with such affiliation perform differently from the so-called independent firms (Limphapayom \& Kim, 1997; Mehadi $\&$ Mazumder, 2017). The absence of this type of corporate governance mechanism underscores the importance of managerial ownership in the market environment such as Thailand.

Together, the absence of a market for corporate control, sufficient investor protection and the absence of such governance mechanisms as keiretsu make Thailand a unique setting; one that is influenced, in large part, by internal governance mechanisms. Singapore represents market with better outside monitoring system than Thailand (Johnson et al., 2000; La Porta et al., 2000), yet with much less active market for corporate control than in the U.S. and U.K. As such, Singapore and Thailand are very good alternatives to test for the relation between ownership and firm value. The implications about the relation between ownership and firm value is also significant to countries where market for corporate control is yet to be fully developed. Whether managerial stock holding enhances firm value is still a very important question for investors in such countries and for those who are considering investment in them.

Using a cross section of 205 non-financial firms listed on Stock Exchange of Thailand (SET) in 1992 and 1993 and 112 non-financial firms on the Singapore Exchange in 1991 and 1992, we find significant evidence to support the convergence of interest hypothesis. We find that, consistent with Jensen and Meckling (1976) and Stulz (1988), managerial ownership has a significantly positive relation with firm value. Our results show that the positive relation remains significant under different model specifications, i.e., OLS and simultaneous equation regression (2SLS). We avoid making any argument on the endogeneity of the relation. We have a rather limited ambition that is to utilize the alternative settings that is free of market forces, to determine if firm value is a function of managerial ownership, and if so to determine if the relation is robust regardless of model specifications.

The paper is organized as follows. The next section we discuss the background of the empirical evidence on the 
relations between ownership and firm value. In the third section, we present the research questions. Then, we present data and research methodology, discuss the empirical results, and conclude the paper.

\section{Background}

\subsection{Single-Equation Studies}

Jensen and Meckling (1976) argue that managerial stock ownership affects firm value. In particular, they argue that increased managerial stock ownership increases shareholder wealth by better aligning managers' interest with those of shareholders. Various empirical studies identify managerial stock ownership as one of the determinants of firm value (Morck et al., 1988; McConnell \& Servaes, 1990). Both studies find evidence to support the convergence of interest hypothesis at the insider ownership level below 5 percent. Many authors such as Morck et al. (1988) and McConnell and Servaes (1990) acknowledge in their caveats that ownership may be determined endogenously (see also Limphapayom \& Polwitoon, 2004; Vijayakumaran \& Vijayakumaran, 2019).

Himmelberg, Hubbard, and Palia (1999) suggest that, to remedy the endogeneity concern, focusing on ownership changes would be useful to understand the relation between firm value and ownership. Fahlenbrach and Stulz (2009), by examining changes in managerial ownership, find that managers increase stock holding when firm perform well and vice versa. Fabisik et al. (2019) expand the work of Fahlenbrach and Stulz (2009) and find that, for all cap stocks, the relation is negative. By restricting to only large cap firms, the results in Fabisik et al. (2019) support the alignment of interest and managerial entrenchment, i.e. the relation is the inverted U-shape. Given the inconsistent empirical results of the relationship between insider ownership and firm value, the question frequently asked is whether managers make better decisions because they own more stock, or whether they own more stock because their firms have better performance.

\subsection{Simultaneous Equations Studies}

Demsetz and Lehn (1985) are among the first who treat ownership as an endogenous variable. Accounting for the endogeneity of ownership, the authors use recursive regression to test the relationship between ownership and firm performance and find that there is no relationship between the two. Villalonga (2019) provides historical background and update of the debate on the endogeneity of ownership.
Loderer and Martin (1997), L\&M hereafter, cast the relationship between ownership and firm value in a structural equation framework. The authors find that, like Demsetz and Lehn (1985), the causality runs from firm value to insider ownership. Cho (1998), Cho hereafter, confirms the existence of such a relation. These two studies provide empirical evidence that ownership is endogenous, and that ownership is a function of firm value. The results in L\&M and Cho are of interest to our paper because they share the time period with our study thus underscoring our assumption that the effects of market forces might in fact cause the inconsistent results found on the U.S. studies.

One important difference between results in L\&M and Cho is the signs of the coefficients related to firm value as measured by Tobin's q. In L\&M, the q ratios have a significantly negative relationship to insider ownership (pp. 239), whereas in Cho, the q ratios have a significantly positive relationship to ownership (pp.117). L\&M offers two interpretations for the negative relationship. First, managers of high q firms have more incentive to liquidate their stock than hold on to it. The managers do so for diversification reason, especially if their human capital is firm-specific. Second, the negative relationship may be attributed to the fact that managers in underperforming firms increase their stock holding in order to window-dress the situation. According to Cho, managers holding on to more stock when their firms have better prospects cause the positive relationship between Q and ownership.

We summarize the results under simultaneous equation regressions from Cho and L\&M as follow:

\begin{tabular}{|c|c|c|}
\hline Variables & Cho's & L\&M's \\
\hline \multicolumn{3}{|c|}{ Firm Value equations (Tobin's q proxy): } \\
\hline InsOwn & + , insignificant & - , insignificant \\
\hline InsOwn ${ }^{2}$ & + , insignificant & $\mathrm{N} / \mathrm{A}$ \\
\hline Firm size & - , significant & -, insignificant \\
\hline Firm risk & N/A & + , significant \\
\hline Capex & + , significant & N/A \\
\hline Leverage & - , insignificant & N/A \\
\hline \multicolumn{3}{|c|}{ Ownership equations (Insider ownership): } \\
\hline Q & + , significant & - , significant \\
\hline \multirow[t]{2}{*}{ Firm size } & -, sig., insignificant & -, significant, significant \\
\hline & (MVE, asset) & (MVE, sales) \\
\hline Firm risk & + , insignificant & + , significant \\
\hline Liquidity & + , insignificant & N/A \\
\hline
\end{tabular}




\section{Research Questions}

While the extant theory and empirical evidence suggest that firm value is a function of ownership, the more recent studies employing different model specification suggest otherwise. The relation between firm value and ownership found under simultaneous equations, however, might be driven by sample-specific factors. L\&M uses a sample of firms that made acquisitions during 1978-1988 whereas Cho looks at 326 Fortune 500 firms in 1991. The studies report the opposite effect of firm value on insider stock ownership. While L\&M reports that firm value has a positive effect on managerial stock ownership, the Cho study reports otherwise. Taken at face value, the results suggest that insiders of firms engaging in corporate acquisitions act differently from those of non-acquiring firms when it comes to equity ownership. It might also suggest that in acquisitions paid by stocks, managers of the acquiring firms use over-valued stocks, which they do not want to own, to pay for the acquisition. Besides differences in sample, the two studies employ different specifications. The different results might as well due to different model specifications including a different choice of variables.

The proponents of structural equation studies argue that the results obtained with single-equation studies are sensitive to model specification. L\&M uses a system of two equations, including three predetermined variables, to investigate the relationship between firm value and ownership. Cho argues that investment is the link between ownership and firm value. He uses a system of three equations, including five predetermined variables, to investigate the relationship among ownership, investment and firm value.

Specifically, L\&M express the relationship as:

Insider ownership $=f($ Firm value, sales, standard deviation of stock price, variance of stock price),

Firm value $=g($ Insider ownership, sales, dummy variable indicate type of payment for acquisition).

Cho express the relationship as: (All with industry dummy)

Insider ownership $=f($ Market value of equity, firm value, investment, volatility of earnings),

Firm value $=g($ Insider ownership, investment, financial leverage, asset size)

Investment $=h($ Insider ownership, firm value, volatility of earning, liquidity)

L\&M acknowledge that their specification is somewhat arbitrary (p. 236). The specification in Cho is more carefully developed. Neither specification has ever been tested elsewhere. Both studies consistently find that ownership is a function of firm value. However, the signs on the coefficient for firm value are opposite. From model perspective, our question is that whether the different results are driven by the difference in sample and model specification. In other words, the issues are whether the two different specifications yield the same results on the same sample, and whether the same specification yields consistent results when employed on different sample.

In this paper, we ask two questions. First, is firm value a function of ownership? Second, in a "naturally controlled setting" where outside governance mechanisms are weak, do different specifications yield consistent results regarding the relationship between firm value and ownership? Since no specification can be proven right in this case, we employ both single-equation model and the two simultaneous equation frameworks introduced by L\&M and Cho on a sample of non-financial companies listed on Singapore Stock Exchange and the Stock Exchange of Thailand (SET).

\section{Data and Methodology}

For comparison purpose, we place our study squarely with the previous studies on U.S. Our period of study (19921993) is the same period as in Cho. We employ the same specification as in L\&M and in Cho on the Singapore and Thai data.

We use a cross section of all non-financial companies listed on the Stock Exchange of Thailand during 1992 and 1993. There are 248, 279 and 322 non-financial firms in 1991, 1992 and 1993. Companies that are included in the study are those that 1) appear in PACAP financial statement file from 1991-1993, and 2) have financial data to compute Tobin's q proxy. As for the Singapore sample, there are 161 and 174 non-financial firms with financial statement data available for 1991 and 1992 of which 152 and 120 firms have ownership data available in 1991 and 1992 respectively. Merging sample firms that have financial data and ownership data available, we are left with 112 firms that appear on PACAP database from 1990 to 1992 . The ownership data for Thai firms is available for 1992 and 1993, and that for Singapore firms is available from 1991 and 1992.

We obtain financial statement data from the PACAP database at the Sandra-Ann Morsilli Pacific-Basin Capital Markets (PACAP) Research Center at the University of Rhode Island. Ownership data for Thai firms is obtained from CD-ROM database provided by Manager Information System, Ltd., (Thailand), the maker of Thailand Company Handbook. Singapore firms' ownership data is collected from Company Handbook available at the PACAP Research center. Table 1 presents descriptions of variables used in this study.

In selecting and measuring the variables, we follow Cho and L\&M. We measure all variables at year-end. McConnell 
Table 1: Descriptions of Variables

\begin{tabular}{|l|l|}
\hline \multicolumn{1}{|c|}{ Variables } & \multicolumn{1}{c|}{ Descriptions } \\
\hline Asset size (ASSET) & Natural logarithm of total assets (in thousand baht and Singapore dollar) \\
\hline Cash flow (LIQUID) & Net income after dividend payments plus depreciation divided by total assets \\
\hline Capital expenditure (CAPEX) & Increase (decrease) in capital investment plus depreciation divided by total assets \\
\hline Financial leverage (LEVER) & Lag value of total liability divided by total assets \\
\hline Insider ownership (INS) & Percentage of insider ownership \\
\hline Long-term debt (DEBT) & Long-term debt divided by total assets \\
\hline Market value of equity (MVE) & Market value of equity (in millions of local currency) \\
\hline $\begin{array}{l}\text { Monthly standard deviation of stock } \\
\text { returns (STDSTK) }\end{array}$ & $\begin{array}{l}\text { Monthly standard deviation of firm i's stock returns over 1987-1992 for both countries, } \\
1988-1993 \text { for Thailand and 1988-1991 for Singapore }\end{array}$ \\
\hline $\begin{array}{l}\text { Monthly variance of stock returns } \\
\text { (VARSTK) }\end{array}$ & $\begin{array}{l}\text { Monthly variance of firm i's stock returns over 1987-1992 for both countries, 1988- } \\
1993 \text { for Thailand and 1988-1991 for Singapore }\end{array}$ \\
\hline Sales (SALES) & Natural logarithm of annual sales (in thousand) \\
\hline Tobin's q proxy (Q) & $\begin{array}{l}\text { Market value of equity plus book value of long-term debt plus book value of short- } \\
\text { term debt divided by book value of assets }\end{array}$ \\
\hline Volatility of earnings (VARPRO) & $\begin{array}{l}\text { Standard deviation of change in profit rate in the period of 1987-1992 and 1988-1993 } \\
\text { for 1992 and 1993 samples respectively }\end{array}$ \\
\hline Industry (IND) & \begin{tabular}{l} 
Industry dummy based on PACAP-Thailand industry codes \\
\hline
\end{tabular}
\end{tabular}

and Servaes (1990) use six as cutoff point for Tobin's q ratio. We use eight as a cutoff point simply because the average $q$ ratio of Thai firms is higher than U.S. firms. As a result, we have left with a sample of 205 firms.

Table 2 contains summary descriptive statistics of the sample. Table 2 Panel A describes variables for the Thai sample. The mean of share ownership of officers and board of directors of Thai firms is $18.7 \%$ in 1992 and $18.05 \%$ in 1993 , compared with 326 Fortune 500 firms in Cho's sample that report the mean of $12.14 \%$ in 1991 . There are 55 Thai firms in 1992, and 59 in 1993 that have 0\% insider ownership. Tobin's q has a mean of 1.99 and 2.13 in 1992 and 1993 respectively, compared with the U.S. firms of 1.1 and 1.3 in 1990 and 1991. In our 1993 sample, there two firms with q greater than 6. There are also two firms in Cho's sample with $\mathrm{q}$ greater than six. These two firms do not influence our regression results. Among the 205 sample firms, there are some firms with missing financial data to compute the variables. The variable that has the most missing data is volatility of earning (VARPRO). There are 194 and 195 observations of VARPRO in 1992 and 1993. As a result, the Cho's model that includes VARPRO uses 194 and 195 observations in 1992 and 1993 analysis.

Table 2 Panel B presents the variables used in the study for Singapore firms. On average, Singapore firms have unusually large q value with a mean of 9.6 and 8.13 and a median of 8.9 and 7.7 in 1991 and 1992 respectively. In order to preserve the sample size, we do not use any cutoff point for q proxy because the median value of the Singaporean data is well over the cutoff point of eight that we use for the Thai data. The mean of insider share ownership of the Singaporean firms is $14 \%$ and $10 \%$, lower than that of the Thai firm. On the contrary, most insiders of Singaporean firm own some part of their company. Only seven firms in 1991 and 12 firms in 1992 have 0\% of insider ownership.

Table 3 reports the distributions of the sample statistics, ranked by level of insider ownership. Table 3 Panel A shows that about $50 \%$ of Thai firms have insider ownership less than $10 \%$, compared with about $68 \%$ of U.S. firms with insider ownership less than $10 \%$. On the other end, about $20 \%$ of Thai firms have insider ownership more than $40 \%$ compared with $10 \%$ of U.S. firms. Table 3 Panel A also suggests that there is positive relationship between q proxy and ownership level of the Thai firms. Such positive relationship is not present in the Singaporean data as shown in Table 3 Panel B. About $60 \%$ of Singaporean firms have their insiders holding between some fractions of a percent to $10 \%$ of the firms share outstanding.

Following L\&M, we estimate the following system of equations under two-stage least square (2SLS):

$$
\begin{aligned}
\mathrm{Q}_{\mathrm{i}}= & \gamma_{12} \mathrm{INS}+\beta_{11} \mathrm{SALES}+\beta_{12} \mathrm{IND}+\varepsilon_{1 \mathrm{i}} \\
\mathrm{INS}_{\mathrm{i}}= & \gamma_{21} \mathrm{Q}+\beta_{21} \mathrm{SALES}+\beta_{22} \text { STDSTK }+\beta_{23} \text { VARSTK }+ \\
& \beta_{24} \mathrm{IND}+\varepsilon_{2 \mathrm{i}}
\end{aligned}
$$


Table 2: Sample Summary Statistics

Panel A: Thailand

\begin{tabular}{|l|c|c|c|c|c|c|}
\hline \multirow{2}{*}{ Variables } & \multicolumn{3}{|c|}{1992} & \multicolumn{3}{c|}{1993} \\
\cline { 2 - 7 } & Mean & Median & STD & Mean & Median & STD \\
\hline INS ${ }^{*}$ & 18.70 & 9.10 & 21.47 & 18.05 & 8.92 & 20.83 \\
\hline $\mathrm{Q}$ & 1.99 & 1.79 & 0.86 & 2.13 & 1.84 & 0.105 \\
\hline CAPEX & 0.11 & 0.08 & 0.16 & 0.07 & 0.12 \\
\hline MVE & $3,651.29$ & $1,469.00$ & $8,535.26$ & $5,351.98$ & $1,628.00$ & $1,270.57$ \\
\hline SALES & 13.58 & 13.52 & 1.16 & 13.67 & 13.63 & 1.17 \\
\hline ASSET & 14.08 & 13.93 & 1.07 & 14.25 & 14.16 & 1.07 \\
\hline LEVER & 0.46 & 0.47 & 0.19 & 0.47 & 0.48 & 0.19 \\
\hline LIQUID & 0.11 & 0.10 & 0.09 & 0.08 & 0.08 & 0.08 \\
\hline STDSTK & 0.16 & 0.14 & 0.06 & 0.16 & 0.15 & 0.06 \\
\hline VARPRO & 0.04 & 0.03 & 0.04 & 0.04 & 0.03 & 0.04 \\
\hline
\end{tabular}

${ }^{a}$ For 1992 , quartile $1=0 \%$, quartile $3=31.08 \%$; for 1993 quartile $1=0 \%$, quartile $3=30.54 \%$.

Panel B: Singapore

\begin{tabular}{|l|c|c|c|c|c|c|}
\hline \multirow{2}{*}{ Variables } & \multicolumn{3}{|c|}{1991} & \multicolumn{3}{c|}{1992} \\
\cline { 2 - 7 } & Mean & Median & STD & Mean & Median & STD \\
\hline INS & 13.79 & 6.45 & 18.24 & 9.79 & 3.31 & 15.61 \\
\hline Q & 9.62 & 8.88 & 4.76 & 8.13 & 7.67 & 0.02 \\
\hline CAPEX & 0.05 & 0.02 & 0.15 & 0.03 & 0.14 \\
\hline MVE & 3372.72 & 1624.86 & 3899.54 & 3965.13 & 1596.00 & 5145.84 \\
\hline SALES & 11.40 & 11.67 & 1.57 & 11.43 & 11.68 & 1.69 \\
\hline ASSET & 12.33 & 12.32 & 1.17 & 12.52 & 12.46 & 1.27 \\
\hline LEVER & 0.37 & 0.38 & 0.19 & 0.38 & 0.38 & 0.18 \\
\hline LIQUID & 0.06 & 0.05 & 0.13 & 0.05 & 0.05 & 0.07 \\
\hline STDSTK & 0.12 & 0.12 & 0.04 & 0.10 & 0.10 & 0.04 \\
\hline VARPRO & 0.11 & 0.04 & 0.29 & 0.09 & 0.04 & 0.13 \\
\hline
\end{tabular}

We try to preserve the model specification used in L\&M because our purpose is to investigate how this specification fares under a different sample. Equations (1) and (2) are also similar to those used by Demsetz and Lehn (1985), but the 2SLS specification is introduced by L\&M. To account for the non-linear relationship between stock price volatility and ownership, L\&M expand Demsetz and Lehn (1985) model by adding VARSTK into eq. (2). The small change we made is to drop from eq. (1) a dummy variable for type of acquisition financing used in L\&M study because our sample does not comprise of acquisition firms. We also add an industry dummy variable to control for industry effect as in Morck et al. (1988).

L\&M estimates eq. (1) in isolation and report a negative coefficient of INS. The authors argue that the negative coefficient of INS is driven by the choice of size variable (p. 235). They argue that the choice of size proxy, between natural logarithm of sales (SALES) and that of market value of firm, makes a difference in the sign of INS. We use two different size proxies such as natural logarithm of book value of asset and market value of equity. We also estimate the firm value equation (eq.1) in isolation. Our specification is consistent with extant literature (Morck et al., 1988; McConnell \& Servaes, 1990).

In the spirit of Morck et al. (1998), Cho assumes two changes in the slope coefficient on insider ownership. We select the breakpoints that best fit the data resulting breakpoints at $5 \%$ and $40 \%$. We use the $5 \%$ and $40 \%$ breakpoints when estimating 2 SLS using Cho's specification. In specific, $I N S_{\mathrm{i}}$ is the insider ownership level for firm. $I N S 1_{\mathrm{i}}$ 
Table 3: Firm Characteristic by Level of Insider Ownerships

Panel A: Thailand

\begin{tabular}{|c|c|c|c|c|c|c|c|c|}
\hline \multirow{2}{*}{ INS } & \multicolumn{9}{|c|}{1992} & \multicolumn{4}{|c|}{1993} \\
\cline { 2 - 9 } & $\mathbf{N}$ & $\mathbf{Q}$ & CAPEX & MVE & $\mathbf{N}$ & $\mathbf{Q}$ & CAPEX & MVE \\
\hline 0 & 55 & 1.78 & 0.08 & $5,729.91$ & 59 & 1.88 & 0.06 & $7,139.57$ \\
\hline$(0,5)$ & 32 & 1.77 & 0.09 & $2,710.75$ & 23 & 1.88 & 0.07 & $3,604.67$ \\
\hline$[5,10)$ & 20 & 1.95 & 0.06 & $1,571.67$ & 24 & 1.99 & 0.06 & $3,879.05$ \\
\hline$[10,20)$ & 23 & 1.69 & 0.17 & $2,812.87$ & 27 & 1.85 & 0.09 & $3,732.81$ \\
\hline$[20,30)$ & 21 & 2.05 & 0.17 & $2,019.60$ & 19 & 2.42 & 0.05 & $5,318.72$ \\
\hline$[30,40)$ & 11 & 2.34 & 0.10 & $7,239.04$ & 14 & 3.40 & 0.08 & $1,329.98$ \\
\hline$[40,50)$ & 14 & 2.39 & 0.10 & $4,842.15$ & 15 & 2.70 & 0.10 & $4,453.84$ \\
\hline$[50,60)$ & 16 & 2.56 & 0.14 & $2,049.38$ & 12 & 2.28 & 0.07 & $2,083.19$ \\
\hline$\geq 60$ & 13 & 2.49 & 0.09 & $2,079.62$ & 12 & 1.99 & 0.07 & $1,672.62$ \\
\hline
\end{tabular}

Panel B: Singapore

\begin{tabular}{|c|c|c|c|c|c|c|c|c|}
\hline \multirow{2}{*}{ INS } & \multicolumn{4}{|c|}{1991} & \multicolumn{4}{|c|}{1992} \\
\cline { 2 - 9 } & $\mathbf{N}$ & $\mathbf{Q}$ & CAPEX & MVE & $\mathbf{N}$ & $\mathbf{Q}$ & CAPEX & MVE \\
\hline 0 & 7 & 10.45 & 0.04 & $5,736.57$ & 12 & 8.59 & 0.06 & $3,320.62$ \\
\hline$(0,5)$ & 41 & 9.17 & 0.04 & $3,386.11$ & 40 & 8.04 & 0.04 & $4,318.29$ \\
\hline$[5,10)$ & 19 & 10.78 & 0.12 & $3,897.37$ & 15 & 6.90 & -0.05 & $5,799.82$ \\
\hline$[10,20)$ & 22 & 7.35 & 0.01 & $2,858.02$ & 10 & 9.68 & 0.04 & $1,637.19$ \\
\hline$[20,30)$ & 9 & 9.79 & 0.02 & $2,785.83$ & 6 & 6.40 & -0.06 & $4,539.65$ \\
\hline$[30,40)$ & 4 & 13.05 & 0.01 & $1,743.40$ & 0 & na & na & na \\
\hline$[40,50)$ & 1 & 10.86 & 0.02 & $1,320.00$ & 5 & 6.90 & 0.05 & 783.74 \\
\hline$[50,60)$ & 5 & 10.34 & 0.12 & $2,312.72$ & 1 & 7.79 & 0.34 & 438.48 \\
\hline$\geq 60$ & 4 & 14.92 & 0.02 & $4,228.69$ & 2 & 17.24 & 0.01 & $5,227.50$ \\
\hline
\end{tabular}

will equal to INS if $0<$ INS $<5 \%$. INS2 2 , will equal to 0 if INS $<5 \%$, or INS $2_{\text {i }}$ will equal INS -5 if $5 \%<=$ INS $<40 \%$. Lastly, INS3 $3_{\mathrm{i}}$ will equal to 0 if INS $<40 \%$, or $I N S 3_{\mathrm{i}}$ will equal INS -40 if INS $=>40 \%$.

Cho hypothesizes that ownership, investment, and firm value are interdependent. He contends that ownership affects firm value by its effect on investment, therefore, investment affects firm value. The author employs simultaneous equations of ownership, investment, and firm value using the two-stage least squares (2SLS) method. Following Cho, we express the model as:

$$
\begin{aligned}
\text { INS }_{\mathrm{i}}= & \gamma_{12} \mathrm{Q}_{\mathrm{i}}+\gamma_{13} \text { CAPEX }_{\mathrm{i}}+\beta_{11} \text { MVE }_{\mathrm{i}}+\beta_{12} \text { VARPRO }_{\mathrm{i}}+ \\
& \beta_{13} \text { LIQUID }_{\mathrm{i}}+\beta_{14} \operatorname{IND}_{\mathrm{i}}+\varepsilon_{1 \mathrm{i}} \\
\mathrm{Q}_{\mathrm{i}}= & \gamma_{23} \text { CAPEX }_{\mathrm{i}}+\gamma_{21} \text { INS1 }_{\mathrm{i}}+\gamma_{22} \mathrm{INS}_{\mathrm{i}}+\gamma_{23} \mathrm{INS}_{\mathrm{i}}+ \\
& \beta_{21} \text { LEVER }_{\mathrm{i}}+\beta_{22} \text { SALES }_{\mathrm{i}}+\beta_{23} \text { IND }_{\mathrm{i}}+\varepsilon_{2 \mathrm{i}}
\end{aligned}
$$

$$
\begin{aligned}
\text { CAPEX }_{\mathrm{i}}= & \gamma_{32} \mathrm{Q}_{\mathrm{i}}+\gamma_{31} \text { INS }_{\mathrm{i}}+\gamma_{22} \text { INS }_{\mathrm{i}}+\gamma_{23} \text { INS3 }_{\mathrm{i}} \\
& +\beta_{31} \text { VARPRO }_{\mathrm{i}}+\beta_{32} \text { LIQUID }_{\mathrm{i}}+\beta_{33} \text { IND }_{\mathrm{i}}+\varepsilon_{1 \mathrm{i}}
\end{aligned}
$$

The ownership equation eq. (3) is similar to eq. (2) in that it expresses ownership as a function of firm value, size and risk plus investment and cash flow. Equation (4), the value equation, is similar to eq. (1), but also includes investment and a lagged value of leverage. This equation is also similar to one that is widely used under a single equation framework. The last equation, eq. (5), the investment equation, expresses investment as a function of ownership, firm value or investment opportunity, firm risk, and cash flow. This equation is developed in spirit of Hoshi, Kashyap and Scharfstein (1991) and Kaplan and Zingales (1997). Cho argues that cash flow affects investment (eq. (5) and investment affects firm value (eq. (4), thus investment 
and cash flow may affect ownership (eq. (3) and they all are determined simultaneously in a system of equation.

\section{Empirical Results}

Table 4 reports regression results from piecewise linear regression similar to Morck et al. (1988). We use the insider ownership break point of $5 \%$ and $40 \%$. Our break points are different from those of Morck et al. (1988) that use 5\% and $25 \%$. We estimate using various ownership break points and find that the break point of $40 \%$ fit our data the best. Due to data availability, we use only 2 control variables, longterm debt and replacement cost, as oppose to four control variables as in Morck et al. (1988).

Table 4 Panel A presents results for Thailand. The preliminary results from the piecewise OLS in Panel

Table 4: Piecewise OLS Results

Panel A: Thailand

\begin{tabular}{|l|c|c|c|c|c|c|c|c|}
\hline \multirow{2}{*}{} & \multicolumn{9}{|c|}{1992} & \multicolumn{3}{c|}{1993} \\
\cline { 2 - 9 } & $\mathbf{Q}$ & $\mathbf{Q}$ & $\mathbf{R O E}$ & $\mathbf{R O E}$ & $\mathbf{Q}$ & $\mathbf{Q}$ & ROE & ROE \\
\hline \multirow{2}{*}{ INS1 } & 0.60 & -1.35 & 0.61 & 0.61 & 0.96 & 0.85 & 1.60 & 1.59 \\
& $(0.15)$ & $(-0.33)$ & $(1.05)$ & $(1.04)$ & $(0.20)$ & $(0.18)$ & $(2.89)$ & $(2.91)$ \\
\hline \multirow{2}{*}{ INS2 } & 1.76 & 1.35 & 0.16 & 0.12 & 3.27 & 3.08 & 0.01 & -0.05 \\
& $(2.51)$ & $(1.86)$ & $(1.50)$ & $(1.13)$ & $(3.73)$ & $(3.38)$ & $(0.12)$ & $(-0.50)$ \\
\hline \multirow{2}{*}{ INS3 } & -0.05 & 0.29 & -0.24 & -0.09 & -4.65 & -4.83 & -0.34 & -0.15 \\
& $(-0.04)$ & $(0.24)$ & $(-1.40)$ & $(-0.55)$ & $(-2.74)$ & $(-2.69)$ & $(-1.73)$ & $(-0.76)$ \\
\hline \multirow{2}{*}{ DEBT } & & -0.80 & & 0.01 & & -0.62 & & -0.04 \\
& & $(-1.58)$ & & $(0.16)$ & & $(-0.90)$ & & $(-0.57)$ \\
\hline \multirow{2}{*}{ ASSET } & & -0.17 & & 0.01 & & 0.01 & & 0.01 \\
& & $(-2.63)$ & & $(1.59)$ & & $(0.12)$ & & $(1.06)$ \\
\hline IND & No & Yes & No & Yes & No & Yes & No & Yes \\
\hline Adjust R-Sq. & 0.09 & 0.15 & 0.03 & 0.19 & 0.12 & 0.17 & 0.07 & 0.16 \\
\hline F-statistics & 7.12 & 2.69 & 3.02 & 3.25 & 8.79 & 2.82 & 5.34 & 2.73 \\
\hline p-value & $<.001$ & $<.001$ & $<.001$ & $<.001$ & $<.001$ & $<.001$ & $<.001$ & $<.001$ \\
\hline
\end{tabular}

t-statistics are in parenthesis.

Panel B: Singapore

\begin{tabular}{|l|c|c|c|c|c|c|c|c|}
\hline \multirow{2}{*}{} & \multicolumn{9}{|c|}{1991} & \multicolumn{4}{c|}{1992} \\
\cline { 2 - 9 } & $\mathbf{Q}$ & $\mathbf{Q}$ & $\mathbf{R O E}$ & $\mathbf{R O E}$ & $\mathbf{Q}$ & $\mathbf{Q}$ & ROE & ROE \\
\hline \multirow{2}{*}{ INS1 $^{\mathrm{a}}$} & -13.58 & -26.34 & -1.89 & -1.88 & -19.28 & 2.53 & -2.58 & -2.32 \\
& $(-0.45)$ & $(-0.94)$ & $(-0.88)$ & $(-0.91)$ & $(-0.79)$ & $(0.11)$ & $(-1.49)$ & $(-1.28)$ \\
\hline \multirow{2}{*}{ INS2 $^{\mathrm{b}}$} & 2.69 & 3.16 & -0.75 & -0.51 & -6.41 & -10.52 & 0.02 & -0.12 \\
& $(0.44)$ & $(0.55)$ & $(-1.70)$ & $(-1.22)$ & $(-1.16)$ & $(-1.89)$ & $(0.04)$ & $(-0.28)$ \\
\hline \multirow{2}{*}{ INS3 $^{\mathrm{c}}$} & 10.61 & 14.26 & 1.98 & 1.48 & 31.85 & 35.26 & 0.69 & 0.55 \\
& $(1.34)$ & $(1.92)$ & $(3.51)$ & $(2.70)$ & $(3.60)$ & $(4.20)$ & $(1.10)$ & $(0.86)$ \\
\hline \multirow{2}{*}{ DEBT } & & -7.97 & & -0.70 & & -4.55 & & -0.01 \\
& & $(-1.94)$ & & $(-2.33)$ & & $(-1.40)$ & & $(-0.02)$ \\
\hline \multirow{2}{*}{ ASSET } & & -0.28 & & -0.01 & & -0.30 & & -0.01 \\
& & $(-0.68)$ & & $(-0.44)$ & & $(-0.87)$ & & $(-0.29)$ \\
\hline IND & No & Yes & No & Yes & No & Yes & No & Yes \\
\hline Adjust R-Sq. & 0.02 & 0.22 & 0.10 & 0.24 & 0.12 & 0.31 & 0.01 & 0.001 \\
\hline F-statistics & 1.64 & 4.05 & 5.00 & 4.33 & 5.06 & 3.60 & 1.33 & 1.00 \\
\hline p-value & 0.18 & $<.001$ & $<.001$ & $<.001$ & $<.001$ & $<.001$ & 0.27 & 0.45 \\
\hline
\end{tabular}


A support our argument that in an environment such as Thailand insider ownership might become an important mechanism to align interest of manager and shareholders. The coefficients of INS2, insider ownership between $5 \%$ to $40 \%$, for the Tobin's q equations are significant for both years for the Thai data.

The results from 1993 sample also support the entrenchment hypothesis at high levels of ownership as indicated by a negatively significant coefficient of INS3. It should be noted that the explanatory power of our model is much higher than those usually found on U.S. studies, even our sample size is much smaller. For example, L\&M report an R-Sq of $0.001, \mathrm{~N}=867$, Cho's piecewise regression R-sq of 0.014, N=326, and McConnell and Servaes (1990)'s R-sq of $0.06, \mathrm{~N}=1100$. As for ROE equation, the 1993 sample provides supporting result to both interest alignment and entrenchment hypothesis.

The results from the Singapore sample are reported in Table 4 Panel B. The relationship between insider ownership and firm value is rather weak in the Singapore sample. The coefficients of ownerships are positively significant at ownership only at the level of $40 \%$ and above. We do not find any entrenchment effect in the Singapore sample. Surprisingly, at the lowest level of ownership, the ownership coefficients register an unexpectedly negative but insignificant sign. The weaker relation between insider ownership and firm value found in Singapore supports our earlier conjecture that in a market similar to Thailand but with better investor protection, the relationship should not be as pronounced as what we find in Thailand.

Table 5 shows the results of 2SLS regression replicating L\&M specifications. Table 5 Panel A reports results from the Thai data. Column 1 and 3 report insider ownership equation (eq.2) and column 2 and 4 report the firm value equation (eq.1). The primary result is that insider ownership coefficients in the firm value equation remain significant for both years and that endogeneity does not affect the results of OLS regression (recall that on U.S. sample the causation that runs from ownership to firm value shift under 2SLS). L\&M reports negatively significant coefficient of Tobin's q in the ownership equation, whereas ours are positively significant in both in 1992 in 1993.

The control variable SALES is also significant with the expected sign. The negative coefficients of SALES in the ownership equation capture the wealth constraint argument. For example, it is suggested that insiders hold smaller proportions of larger firms than small firms. L\&M report a negatively significant coefficient of SALES in their firm value equation, whereas ours is positively significant. We argue that the positive effect of SALES on firm value should be expected since high sales in general should be associated with good performance.
Firm risk proxy variables such as STDSTK and VARSTK are also significant with expected sign. The negative sign of coefficient estimates of STDSTK support arguments in Demsetz and Lehn (1985) and L\&M that greater stock price volatility makes it harder to monitor manager thus creating a strong incentive for insiders to assemble large holding (a control potential). Our results on the Thai sample provide support to the previous works advanced in U.S., and more importantly they suggest that managerial ownership affects firm value.

Table 5 Panel B reports results of 2SLS on the Singapore sample. Again, the sign of the ownership coefficients remains positively significant for both years. Similarly, firm value also has a positively significant relation with managerial ownership, but only for the 1991 sample. None of the control variables is significant. However, the explanatory power is much higher than that of the U.S. sample in L\&M. The Singapore results, however, lend support to the main argument of this paper that is there is positive relation between managerial ownership and firm value are weaken in an environment where outside governance is stronger.

Table 6 reports the 2SLS regression results replicating Cho's specifications. We use breakpoints of insider ownerships at $5 \%$ and $40 \%$ in correspond to Cho's $7 \%$ and $38 \%$. Table 6 Panel 1 shows the results from the Thai sample. The most interesting result is that, contradicting Cho's, the coefficients of INS2 in the firm value model are positively significant for both years. Furthermore, the coefficient of INS3 in the firm value equation is negatively significant in 1993.

Consistent with the famous hump-shaped reported in Morck et al. (1988), the results in Panel A suggest that insider ownership has a positive relation with firm value, and that the relationship is concave at the higher level of ownership as shown by the negative effect of INS3. The negative effect of INS3 supports the entrenchment hypothesis. Note that the results from the 2SLS are consistent with those from the OLS in Table 4. This gives us more confidence to argue that firm value is a function of insider ownership regardless of model specifications in a country where market forces are weak.

Consistent with Cho, the coefficients of Tobin's q proxy in the insider ownership equation are positively significant for both years. Other control variables such as size proxies and the firm risk proxy also show the expected signs. For example, the coefficient of MVE is significantly negative in the ownership equation for both years. The coefficients of asset size in firm value equation are also positively significant, consistent with the results of SALES in Table 5. In the capital expenditure equation, the coefficient of LIQUID is positively significant for both years. The results are also consistent with extent literature. 
Table 5: 2SLS Regression Results for L\&M Model

Panel A: Thailand

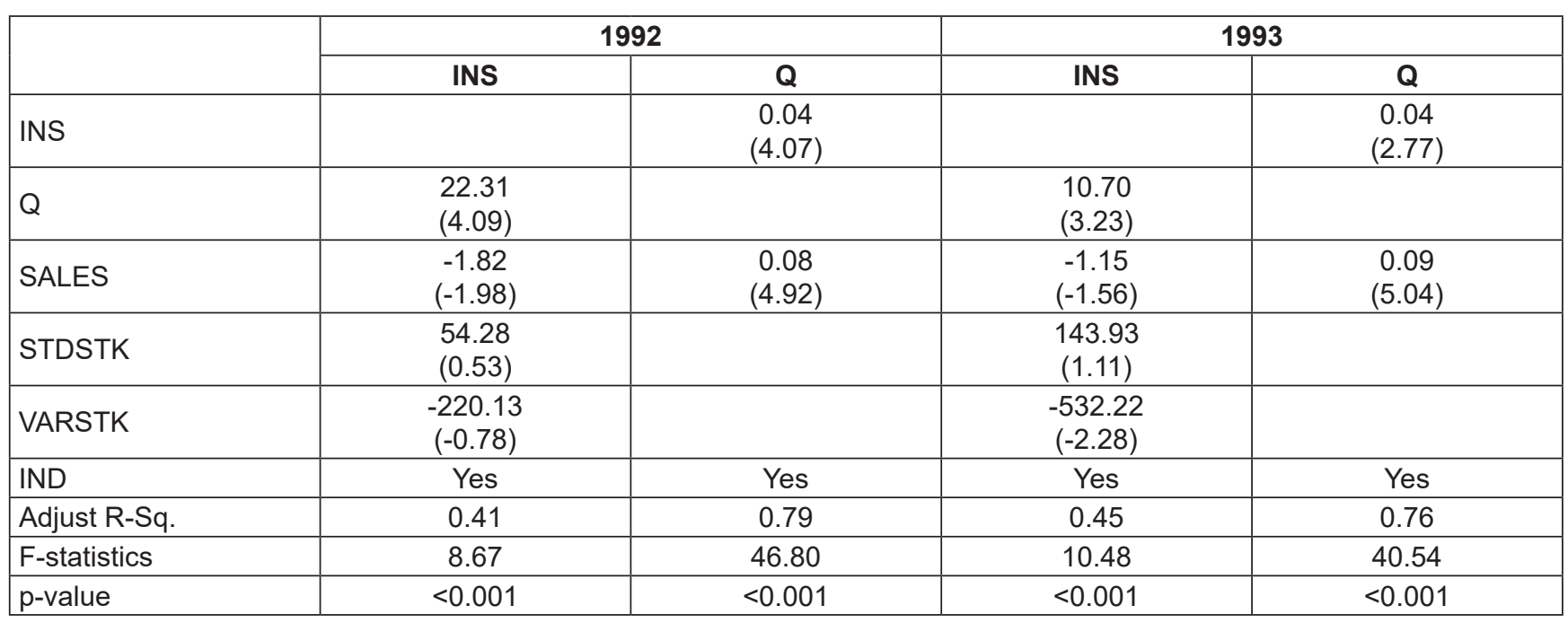

t-statistics are in parenthesis.

Panel B: Singapore

\begin{tabular}{|c|c|c|c|c|}
\hline & & & & \\
\hline & INS & $\mathbf{Q}$ & INS & $\mathbf{Q}$ \\
\hline INS & & $\begin{array}{c}0.50 \\
(1.95) \\
\end{array}$ & & $\begin{array}{c}0.50 \\
(1.66) \\
\end{array}$ \\
\hline Q & $\begin{array}{c}2.02 \\
(1.89) \\
\end{array}$ & & $\begin{array}{c}1.37 \\
(1.40) \\
\end{array}$ & \\
\hline SALES & $\begin{array}{c}-0.62 \\
(-0.57)\end{array}$ & $\begin{array}{c}0.36 \\
(1.12) \\
\end{array}$ & $\begin{array}{c}-0.50 \\
(-0.63)\end{array}$ & $\begin{array}{c}0.33 \\
(1.33) \\
\end{array}$ \\
\hline STDSTK & $\begin{array}{l}-34.92 \\
(-0.27)\end{array}$ & & $\begin{array}{l}26.64 \\
(0.21) \\
\end{array}$ & \\
\hline VARSTK & $\begin{array}{l}179.11 \\
(0.35)\end{array}$ & & $\begin{array}{l}78.56 \\
(0.15) \\
\end{array}$ & \\
\hline IND & Yes & Yes & Yes & Yes \\
\hline Adjust R-Sq. & 0.35 & 0.55 & 0.29 & 0.53 \\
\hline F-statistics & 7.34 & 20 & 4.92 & 14.97 \\
\hline p-value & $<.0001$ & $<.0001$ & $<.0001$ & $<.0001$ \\
\hline
\end{tabular}

Table 6: Two-Stage Least Square Regression Results for Cho Model

Panel A: Thailand

\begin{tabular}{|l|c|c|c|c|c|c|}
\hline \multirow{2}{*}{} & \multicolumn{3}{|c|}{1992} & \multicolumn{3}{c|}{1993} \\
\cline { 2 - 7 } & INS & MVE & CAPEX & INS & 1.97 & 0.32 \\
INS1 & a & 2.50 & 1.42 & & $(0.36)$ & $(0.73)$ \\
\hline \multirow{2}{*}{ INS2 $^{\mathrm{b}}$} & & $(0.63)$ & $(1.99)$ & & 2.57 & 0.00 \\
& & 1.34 & 0.04 & & $(2.44)$ & $(0.05)$ \\
\hline
\end{tabular}




\begin{tabular}{|c|c|c|c|c|c|c|}
\hline & \multicolumn{3}{|c|}{1992} & \multicolumn{3}{|c|}{1993} \\
\hline & INS & MVE & CAPEX & INS & MVE & CAPEX \\
\hline INS3 $^{c}$ & & $\begin{array}{c}0.37 \\
(0.30)\end{array}$ & $\begin{array}{c}-0.20 \\
(-0.92)\end{array}$ & & $\begin{array}{c}-3.93 \\
(-2.08) \\
\end{array}$ & $\begin{array}{l}-0.02 \\
-0.10\end{array}$ \\
\hline Q & $\begin{array}{c}0.09 \\
(3.07) \\
\end{array}$ & & $\begin{array}{c}-0.03 \\
(-1.27)\end{array}$ & $\begin{array}{c}0.10 \\
(2.36) \\
\end{array}$ & & $\begin{array}{c}-0.02 \\
(-1.45)\end{array}$ \\
\hline CAPEX & $\begin{array}{c}-0.64 \\
(-1.00)\end{array}$ & $\begin{array}{c}0.72 \\
(0.45) \\
\end{array}$ & & $\begin{array}{c}2.14 \\
(1.20) \\
\end{array}$ & $\begin{array}{c}8.56 \\
(4.15) \\
\end{array}$ & \\
\hline MVE & $\begin{array}{c}-0.23 \\
(-1.05)\end{array}$ & & & $\begin{array}{c}-0.23 \\
(-1.15)\end{array}$ & & \\
\hline VARPRO & $\begin{array}{c}0.19 \\
(0.31) \\
\end{array}$ & & $\begin{array}{c}0.53 \\
(1.85) \\
\end{array}$ & $\begin{array}{c}0.42 \\
(0.68) \\
\end{array}$ & & $\begin{array}{c}-0.20 \\
(-1.04) \\
\end{array}$ \\
\hline LIQUID & $\begin{array}{c}0.29 \\
(0.84) \\
\end{array}$ & & $\begin{array}{c}0.41 \\
(2.75) \\
\end{array}$ & $\begin{array}{c}-1.59 \\
(-1.19) \\
\end{array}$ & & $\begin{array}{c}0.74 \\
(5.62) \\
\end{array}$ \\
\hline LEVER & & $\begin{array}{c}0.04 \\
(0.12) \\
\end{array}$ & & & $\begin{array}{c}1.67 \\
(2.66) \\
\end{array}$ & \\
\hline ASSET & & $\begin{array}{c}0.09 \\
(3.98)\end{array}$ & & & $\begin{array}{c}0.04 \\
(1.29)\end{array}$ & \\
\hline IND & Yes & Yes & Yes & Yes & Yes & Yes \\
\hline Adjust R-Sq. & 0.41 & 0.85 & 0.38 & 0.27 & 0.75 & 0.44 \\
\hline F-statistics & 7.90 & 53.69 & 6.92 & 4.80 & 30.34 & 8.72 \\
\hline$p$-value & $<0.001$ & $<0.001$ & $<0.001$ & $<0.001$ & $<0.001$ & $<0.001$ \\
\hline
\end{tabular}

Panel B: Singapore

\begin{tabular}{|c|c|c|c|c|c|c|}
\hline & \multicolumn{3}{|c|}{1991} & \multicolumn{3}{|c|}{1992} \\
\hline & INS & MVE & CAPEX & INS & MVE & CAPEX \\
\hline INS1 ${ }^{a}$ & & $\begin{array}{l}-10.79 \\
(-0.19)\end{array}$ & $\begin{array}{c}0.09 \\
(0.16)\end{array}$ & & $\begin{array}{c}6.91 \\
(0.22)\end{array}$ & $\begin{array}{c}-0.54 \\
(-0.74)\end{array}$ \\
\hline INS $^{\mathrm{b}}$ & & $\begin{array}{r}10.02 \\
(0.86)\end{array}$ & $\begin{array}{c}-0.04 \\
(-0.29)\end{array}$ & & $\begin{array}{c}-2.86 \\
(-0.39)\end{array}$ & $\begin{array}{c}0.20 \\
(1.09)\end{array}$ \\
\hline INS3 $^{\circ}$ & & $\begin{array}{c}-0.66 \\
(-0.04)\end{array}$ & $\begin{array}{c}0.08 \\
(0.41)\end{array}$ & & $\begin{array}{l}28.11 \\
(3.01)\end{array}$ & $\begin{array}{c}-0.03 \\
(-0.09)\end{array}$ \\
\hline$Q$ & $\begin{array}{c}0.02 \\
(4.11) \\
\end{array}$ & & $\begin{array}{c}0.00 \\
(0.79) \\
\end{array}$ & $\begin{array}{c}0.03 \\
(2.10) \\
\end{array}$ & & $\begin{array}{c}-0.00 \\
(-0.59)\end{array}$ \\
\hline CAPEX & $\begin{array}{c}0.80 \\
(0.67) \\
\end{array}$ & $\begin{array}{l}86.77 \\
(2.71) \\
\end{array}$ & & $\begin{array}{c}3.26 \\
(1.74) \\
\end{array}$ & $\begin{array}{c}0.89 \\
(0.07) \\
\end{array}$ & \\
\hline MVE & $\begin{array}{c}0.01 \\
(1.50) \\
\end{array}$ & & & $\begin{array}{c}0.01 \\
(0.17) \\
\end{array}$ & & \\
\hline VARPRO & $\begin{array}{c}0.26 \\
(3.77) \\
\end{array}$ & & $\begin{array}{c}0.01 \\
(0.18) \\
\end{array}$ & $\begin{array}{c}-0.29 \\
(-0.85)\end{array}$ & & $\begin{array}{c}0.08 \\
(0.97) \\
\end{array}$ \\
\hline LIQUID & $\begin{array}{c}-0.97 \\
(-2.32)\end{array}$ & & $\begin{array}{c}0.27 \\
(1.80) \\
\end{array}$ & $\begin{array}{c}-2.42 \\
(-2.04) \\
\end{array}$ & & $\begin{array}{c}0.54 \\
(2.71) \\
\end{array}$ \\
\hline LEVER & & $\begin{array}{c}-9.95 \\
(-2.11)\end{array}$ & & & $\begin{array}{c}-2.17 \\
(-0.87) \\
\end{array}$ & \\
\hline ASSET & & $\begin{array}{c}0.96 \\
(3.55)\end{array}$ & & & $\begin{array}{c}0.60 \\
(4.39)\end{array}$ & \\
\hline IND & Yes & Yes & Yes & Yes & Yes & Yes \\
\hline Adjust R-Sq. & 0.49 & 0.57 & 0.16 & 0.03 & 0.84 & 0.08 \\
\hline F-statistics & 11.16 & 13.69 & 2.86 & 1.3 & 39.78 & 1.66 \\
\hline p-value & $<.0001$ & $<.0001$ & 0.00 & 0.25 & $<.0001$ & 0.10 \\
\hline
\end{tabular}


Another interesting result is the sign of the lagged value of leverage ratio in the firm value equation. Cho reports a negatively insignificant coefficient. Ours are positive for both years; the coefficient in 1993 has a $t$-statistics of 2.66. This finding supports the agency benefits of debt advanced by Jensen and Meckling (1976), and it also supports the free cash flow hypothesis (Jensen, 1986).

Table 6 Panel B reports results from the Singapore sample. The only support we find from the Singapore sample is the positively significance of the coefficient of INS3 in 1992. It shows that in the Singapore sample, the relation between ownership and firm value is significant only at the ownership level of $40 \%$ or more. Note that the results from 2SLS are consistent with that from OLS in Table 4. The rather weak result regarding the relation between insider ownership and firm value in Singapore in fact supports our conjecture that better investor protection confounds the effect of managerial ownership on firm value, hence, the Singapore results are not as evidence as those from Thailand.

\section{Conclusion}

In this paper, we ask two questions. First, is firm value a function of managerial ownership? Second, does strong market forces confound the mix results of the relation between managerial ownership and firm value found in U.S. studies? We test the hypotheses on the samples from Singapore Stock Exchange and Stock Exchange of Thailand. The sample period is prior to corporate governance reform undertaken after the Asian financial crisis. During the sample period, the two capital markets provide alternative settings that are, in large part, free of market forces. For ease of comparison, we use various model specifications done on U.S. samples during the same period as our study.

In all, our results provide empirical support to various agency cost hypotheses advanced in U.S. The Singapore results are consistent with the argument that concentration of managerial shareholding benefits firm value. Moreover, the famous inverted U-shape that depicts the relation between managerial ownership and firm value is more pronounced in all specifications in the Thai sample, where market forces are weak, even if our sample is much smaller than those in the U.S. studies. The results are robust under many different model specifications. Our results provide useful implications for investors in emerging and frontier markets where outside governance mechanisms are yet to be fully developed.

\section{References}

Aggarwal, R., Erel, I., Ferreira, M., \& Matos, P. (2011). Does governance travel around the world? Evidence from institutional investors. Journal of Financial Economics, 100(1), 154-181.
Cho, M. (1998). Ownership Structure, investment, and the corporate value: An empirical Analysis. Journal of Financial Economics, 47(1), 103-121. https://doi.org/10.1016/S0304405X(97)00039-1

Demsetz, H., \& Lehn, K. (1985). The structure of corporate ownership: Causes and consequences. Journal of Political Economy, 93(6), 1155-1177. http://dx.doi.org/10.1086/261354

Fabisik, K., Fahlenbrach, R., Stulz, R., \& Taillard, J. (2019). Why Are firms with more managerial ownership worth less? NBER Working Paper No. 25352. Available at https://www.nber.org/ papers/w25352.

Faccio, M., \& Lasfer, M. A. (1999). Managerial ownership, board and firm value: The UK evidence. Cass Business School Research Paper. Available at https://ssrn.com/abstract=179008

Fahlenbrach, R., \& Stulz, R. (2009). Managerial ownership dynamic and firm value. Journal of Financial Economics, 92(3), 342361. https://doi.org/10.1016/j.jfineco.2008.06.005

Harris, M., \& Raviv, A. (1988). Corporate control contests and capital structure. Journal of Financial Economics, 20, 55-86. https://doi.org/10.1016/0304-405X(88)90045-1

Himmelberg, C., Hubbard, R., \& Palia, D. (1999). Understanding the determinants of managerial ownership and performance. Journal of Financial Economics, 53(3), 333-384. https://doi. org/10.1016/S0304-405X(99)00025-2Hoshi, T., Kashyap, A., \& Scharfstein, D. (1991). Corporate structure, liquidity and investment: Evidence from Japanese industrial groups. Quarterly Journal of Economics, 106(1), 33-60. https://doi. org/10.2307/2937905

Jensen, M. (1986). Agency cost of free cash flow, corporate finance and takeovers. American Economics Review, 76(2), 323-329. https://doi.org/10.1111/j.1540-6261.1993.tb04022.x

Jensen, M. C. (1993). The modern industrial revolution, exit, and the failure of internal control systems. Journal of Finance, 48(3), 831-880. https://www.jstor.org/stable/1818789? seq=1

Jensen, M., \& Meckling, W. (1976). Theory of the firm: Managerial behavior, agency costs and ownership structure. Journal of Financial Economics, 3(4), 5-50. https://doi.org/10.1016/0304405X(76)90026-X

Johnson, S., Boone, P., Breach, A., \& Friedman, E. (2000). Corporate governance in the Asian financial crisis. Journal of Financial Economics, 58(1), 141-186. https://doi.org/10.1016/ S0304-405X(00)00069-6

Kaplan, S. N., \& Zingales, L. (1997). Do cash flow sensitivity provide useful measures of financing constraints? Quarterly Journal of Economics, 112(1), 169-215.

Kim, E. H., \& Lu, Y. (2011). CEO ownership, external governance, and risk-taking. Journal of Financial Economics, 102(2), 272292. https://doi.org/10.1016/j.jfineco.2011.07.002

La Porta, R., Lopez-de-Silanes, F., Shleifer, A., \& Vishny, R. W. (2000). Investor protection and corporate governance. Journal of Financial Economics, 58(1), 3-27. https://doi.org/10.1016/ S0304-405X(00)00065-9 
La Porta, R., Lopez-de-Silanes, F., Shleifer, A., \& Vishny, R. W. (1998). Law and Finance. Journal of Political Economy, 106(6), 1113-1155. https://www.jstor.org/ stable $/ 10.1086 / 250042$ ?seq $=1$

Limpaphayom, P., \& Kim, K. A. (1998). A test of the two-tier corporate governance structure: The case of Japanese keiretsu. Journal of Financial Research, 21(1), 37-51. https://doi. org/10.1111/j.1475-6803.1998.tb00268.x

Limpaphayom, P., \& Polwitoon, S. (2004). Bank relationship and firm performance: Evidence from Thailand before the Asian financial crisis. Journal of Business Finance \& Accounting, 31(9), 9-10, 1577-1600. https://doi.org/10.1111/j.0306686X.2004.00585.x

Loderer, C., \& Martin, K. (1997). Executive stock ownership and performance: Tracking faint traces. Journal of Financial Economics, 45(2), 223-255. https://doi.org/10.1016/S0304405X(97)00017-2

McConnell, J., \& Servaes, H. (1990). Additional evidence on equity ownership and corporate value. Journal of Financial Economics, 27(2), 595-612. https://doi.org/10.1016/0304405X(95)00824-X

Mehadi, M.\& Mazumder, M.(2017). Top-executives Compensation: The Role of Corporate Ownership Structure in Japan, Journal of Asian Finance, Economics and Business, 4(3), 35-43. http:// dx.doi.org/10.13106/jafeb.2017.vol4.no3.35
Morck, R., Shleifer, A. \& Vishny, R. (1988). Management ownership and market valuation: An empirical analysis. Journal of Financial Economics, 20, 293-315. https://doi. org/10.1016/0304-405X(88)90048-7

Shleifer, A. \& Vishny, R. W. (1997). A survey of corporate governance. Journal of Finance, 52(2), 737-783. https://doi. org/10.1111/j.1540-6261.1997.tb04820.x

Stulz, R. (1988). Managerial control of voting right: Financing policies of the market for corporate control. Journal of Financial Economics, 20, 25-59. https://doi.org/10.1016/0304405X(88)90039-6

Vijayakumaran, S., \& Vijayakumaran, R. (2019). Corporate Governance and Capital Structure Decisions: Evidence from Chinese Listed Companies, Journal of Asian Finance, Economics and Business, 6(3), 67-79. https://doi.org/10.13106/ jafeb.2019.vol6.no3.67

Villalonga, B. (2019). On ownership structure and corporate performance: Looking back and looking forward. Journal of Corporate Finance, 58, 64-67. https://doi.org/10.1016/j. jcorpfin.2019.04.005

Vu, V. T. T, Phan, N. T., \& Dang, H. N., (2020). Impacts of Ownership Structure on Systemic Risk of Listed Companies in Vietnam, Journal of Asian Finance, Economics and Business, 7(2), 107-117. https://doi.org/10.13106/jafeb.2020.vol7. no2.107 